\title{
Out-of-Pocket Health Care Expenditure and Poverty in Assam
}

\author{
${ }^{1}$ Joel Basumatary, ${ }^{2}$ Nirankar Srivastav \\ ${ }^{1}$ PhD Scholar, Department of Economics, North Eastern Hill University, Shillong, India \\ ${ }^{2}$ Professor, Department of Economics, North Eastern Hill University, Shillong, India
}

\begin{abstract}
Spending on health care is considered as an investment by many countries of the world. Nevertheless, many developing countries hitherto have not allocated sufficient resources to fund their health care systems. Some due to resource constraint but others due to ignorance or health care is not in a political discourse. Out-ofpocket (OOP) spending on health care has the power to distort the economic well-being of the households who make, especially the less income groups. However, in most of the developing countries the medical insurance facility is still in a meager existence and thus, when people get health shocks they have to make the payments from their pocket. This can push the people into the pool of poverty and poverty trap to those who are poor. The percentage of poor people in Assam has been increasing from 34.4\% in 2004-05 to 37.9\% in 2009-10. As per the 'Poverty Estimates for 2011-12', based on the Tendulkar Methodology, around 101.27 lakh or 1.01 crore of Assam's population are categorized as Below Poverty Line (BPL). Furthermore, all through the period from 2004-06 to 2011-13, the maternal mortality ratio (MMR) of Assam has been higher than the all India average. In 2014 Assam had infant mortality rate (IMR) of 49 (equal to all India average) and stands the highest amongst the north eastern states of India. Therefore, this calls for investigating the government spending on health care and subsequently, the amount of OOP spending. Thus, this paper looked into the government health spending and OOP spending on health care.

Based on Reserve Bank of India data on health care spending, it has been found that the public health care spending of Assam is lower than two percent of its Gross State Domestic Product (GSDP). The analysis done based on NSSO $71^{\text {st }}$ round, the OOP expenditure on health care has been higher than North East India average and All India average.

Thus, to mitigate the menace of poverty and increase the health status of the people, the paper concludes that the government spending in Assam on health care needs to be increased beyond the 2\% (or more) of GSDP.
\end{abstract}

Keywords: out-of-pocket, public spending on health care, Assam, North Eastern Region, Poverty

\section{INTRODUCTION}

Grossman theory of demand for health care propagates that spending on health care is an investment, and not wholly a consumption spending. Nonetheless, a poor person has to rethink before making such expenditure. He is coerced to make such spending when he faces health shocks. Thus, he/she has to sacrifice or curtail the consumption of the basic needs like food, clothing and essential consumption needs. Health insurance is one thing which can protect the health and wealth of the people. However, in most of the developing countries insurance facility is either totally absent or exists meagerly. Or in many cases people are too poor to insure themselves (due to necessity of high premium payments in the private insurance facility). Thus, spending from the pocket is the major means to pay for the medical bills. Out-of-pocket (OOP, hereafter) has become a buzzword and a public discourse due to its power to push people into the pool of poverty and into the poverty trap, to those who are already poor. According to the World Health Statistics, 2012 almost 60\% of total health expenditure in India was out-of-pocket in 2009. Comparing with other neighboring countries it was $49 \%$ in Nepal, 44\% in Sri Lanka, 13\% in Bhutan, 65\% in Bangladesh, $41 \%$ in Pakistan, and 38\% in China. However, if we look at the other extreme end, countries which also have high human development index, the OOP spending is rather low. For instance, it was only $7 \%$ in France in 2009, $6 \%$ in the Netherlands, UK only $10 \%$, and only $12 \%$ in Ireland. Thus, developing countries need to put more emphasis on increasing the health care spending. The planning commission (now replaced by NITI Aayog) admits that around 39 million Indians are pushed into poverty because of ill health every year. Furthermore, $30 \%$ in rural India could not go for treatment due to lack of finance in 2004. This is so because high out-of-pocket costs prevent people with long-term or chronic conditions from seeking health care and place financial strain on low income consumers. This is the phenomenon at the national level. However, India is a federal country with 29 states and seven union territories within the union of India. In the constitution of India powers and functions on different subjects are divided between the centre and the states into three viz., Union list, State list, and the concurrent list. The central has got the omnipotent power on parameters listed in the union list, the state has the power to legislate and take actions on sectors which are listed in the state list, but at the same time the central government has the power to 
intervene the state on certain occasions. The items which are listed in the concurrent list are within the jurisdiction of the central as well as the state, but the central government has the power to override in case of any dispute between the state and the centre. Health care is listed in the state list as well as in the union list. Therefore, certain aspects of the health care are taken care by the state and some by the centre. Thus, due to this phenomenon the health status and health care system in India differs from region to region and from one state to the other state. For instance, empirical evidence shows that the southern region is having more robust health care system than the eastern and northern region. Furthermore, states like Kerala and Tamil Nadu are faring better than the other states like Assam, and EAG (Empowered Action Group) states in case of health status of the people.

Assam is a unique state which is connected with the rest of India via a narrow strip in West Bengal called as Chicken's Neck. It is the only major state amongst the eight north eastern states. All through the period from 2004-06 to 2011-13, the maternal mortality ratio (MMR) of Assam has been higher than the all India average. For example, in the period 2004-06, Assam had MMR of 480 as against the all India average of 254. Thus, the MMR of Assam was higher than the all India by 226. However, the difference between the two came down to 133 by 2011-13 (Figure 3). Nevertheless, the MMR of Assam is still higher than the all India average. In fact, the MMR of Assam is even higher than all the EAG (Empowered Action Group) states, which consists of states like BIMARU (Bihar, Madhya Pradesh, Rajasthan, and Uttar Pradesh) plus Uttarakhand, Odisha, Chattisgarh, and Jharkhand. Furthermore, in 2014 Assam had infant mortality rate (IMR) of 49 (equal to all India average) and stands the highest amongst the north eastern states. Likewise, in many health care parameters Assam shows poor performance. Thus, this presents a unique challenge for the state. As per the 'Poverty Estimates for 2011-12', based on the Tendulkar Methodology, around 101.27 lakh or 1.01 crore of Assam's population are categorized as Below Poverty Line (BPL). Thus, 31.98 per cent of Assam's total population is BPL. It is also worthy to reiterate that the number of people falling into poverty level is rather showing an increasing trend. Therefore, it is necessary that health care spending and health care system of the individual states is evaluated, so that stakeholders and policy makers are informed to take pragmatic actions. This paper seeks to investigate the health care spending of the state emphasizing on out-of-pocket spending of the people. The paper is presented as follows: this introduction is followed by the profile of Assam; the third section depicts the data and methodology of the present work; which is followed by the fourth section on findings and discussions; and the fifth section is the conclusion.

\section{PROFILE OF ASSAM}

Assam is a part of the North Eastern States of India located in the southern part of the eastern Himalayas. Assam comprises the Brahmaputra valley and Barak Valley along with the hills of Karbi Anglong and North Cachar. As per the 2011 India census, Assam has a total population of 31,169,272. With the State's total population of $26,638,407$ in 2001 , the decadal population growth rate reached 16.93 per cent in 2011.The density of population of the State as per 2011 census is recorded as 397, against India's density of 382. Thus, Assam is ranked 15th position in terms of density of population in the country. As per the report, in Assam, Kamrup (Metro) district is the most densely populated district with 1313 persons per square km, whereas, the lowest density has been recorded in Dima Hasao district with only 44 persons per square $\mathrm{km}$. Literacy rate of the state reached $73.18 \%$ in 2011 . Out of which male literacy rate was $78.81 \%$ and female literacy rate was $67.27 \%$ (2011 India census).

According to the census report of $2011,86 \%$ lives in rural villages (which means around 2.68 crore persons live in rural areas of Assam as per census report) and 14 per cent of the state's population lives in urban areas. As per 2001 census, the rural population was 87 per cent (Rural Health Statistics, 2011). Furthermore, around 70 per cent of the people of Assam depend on agriculture for their livelihoods. While, many of the states of India have been transforming their economy from agro-based to industrial economy, the economy of Assam is still an agrarian. Assam is the 14th largest state in India and it takes the position of $9^{\text {th }}$ when it comes to population density (population per square $\mathrm{km}$ ), Bihar being at the top which is followed by West Bengal. Thus, as the population of the state increases day by day the state faces a variety of health and health care challenges.

The large areas of Assam covered by the tea gardens provide unparalleled scenic beauty to the state and around 20 per cent of the population of Assam is the tea garden labourers (who are mostly Adivasis). This also presents a unique public health challenges in Assam.

\section{DATA SOURCES AND METHODOLOGY}

This study is based on health spending data from the National Health Accounts, 2004-05, Reserve Bank of India, and the $60^{\text {th }}$ and $71^{\text {st }}$ rounds of NSSO (National Sample Survey Organization). The Gross State Domestic Product of the individual states has been taken from the Economic and Political Weekly Research Foundation. OOP spending on health has been taken from the $60^{\text {th }}$ and $71^{\text {st }}$ rounds of NSSO (National Sample Survey Organization). Medical Expenditure and non-medical expenditure on account of hospitalization per hospitalization case; Average total medical expenditure for treatment per childbirth during stay at hospital (as 
inpatient) over the last 365 days by type of hospital for both rural and urban areas; State wise distribution of OOP by type of sickness/disease and source of treatment and Composition of Out of Pocket Expenditure Inpatient Care (\%) by residence are analyzed. The survey period of the 71st round of NSSO was from January to June 2014. The information was collected from a set of sample households using schedule. The survey period was six months (January to June 2014). The reference period for all ailments (as in-patient or otherwise) during last 15 days were collected. On the other hand, the number of 'hospitalized' members was collected for 365 days (hospitalization occurred from January 2013 to June 2014). Table 1 shows the method of sample surveyed in the state of Assam.

Table No.1: No. of villages/blocks, households and persons surveyed in Assam state

\begin{tabular}{|c|c|c|c|c|c|c|c|}
\hline \multicolumn{2}{|c|}{$\begin{array}{c}\text { (villages/blocks) } \\
\text { surveyed }\end{array}$} & \multicolumn{5}{|c|}{ no. of surveyed } \\
\cline { 2 - 8 } & Households & \multicolumn{3}{c|}{ Persons } \\
\hline Rural & Urban & Rural & Urban & All & Rural & Urban & All \\
\hline 212 & 70 & 1695 & 560 & 2255 & 8757 & 2654 & 11411 \\
\hline
\end{tabular}

Source: NSSO $71^{\text {st }}$ round

\section{IV.1. Government Expenditure on Health Care}

\section{FINDINGS AND DISCUSSIONS}

Spending on health care is an investment, because it brings returns, though in the long run. Thus, demand for health care is both consumption, and an investment. Therefore, health is both consumption good, and a capital good. It is consumption good because health makes people feel better and a capital good, because it increases the number of healthy days to work and to earn income. Like physical capital, health also depreciates over time, that is, with the increase in age the health of a person depreciates and productivity could decline. However, increase in formal schooling increases the value of health capital good. Since health care is a capital good but a public good, if left freely in the market, there is every chance that, many would be left un-served especially in the less developed countries where huge number of people still struggle with the basic necessities of life. OOP spending on health care is one of the biggest problems of our time. People are forced to spend when they face health shocks. It does not differentiate between poor and non-poor, especially so, when there are no subsidized or free government health insurance facilities and the private insurance products are too costly, that a poor person cannot afford to buy. Thus, this phenomenon brings the problem of exclusion. The people who are not able to afford to insure themselves with the only available private insurance facilities will be excluded from accessing the quality health care. Thus, this will bring inequity in the society, which will create social distortions. Therefore, it is important that the government comes out with various schemes to give a minimum quality of health care to its people. The unique challenge for the government of Assam is to tackle economic development and the separatist groups/militants groups who are currently active. People are also in dilemma whether lack of development is the cause of the growth of these anti-social groups, or the presence of these groups is the cause of lack of development. Table no.2 depicts the government spending on health care from 2000-01 to 2013-14. It is seen from the said table that, the health expenditure of the government of Assam is asymmetrical. In 2000-01, it was 0.76 percent of GSDP (Gross state domestic product), but it decreased by 0.14 percent to 0.62 in 2002-03. The highest government spending was 1.35 percent of GSDP in 2009-10. What is clear from table 2 is that, the government health care spending did not touch 2 percent of GSDP in Assam.

Table No.2: Government Expenditure on Health care, Assam

\begin{tabular}{|c|c|c|}
\hline & \multicolumn{2}{|c|}{ Public Health Expenditure (\%of GSDP) } \\
\hline Year & $(2)$ & Changing pattern (increase or decrease from the preceding year) \\
\hline $2000-01$ & 0.76 & 0 \\
\hline $2001-02$ & 0.76 & 0 \\
\hline $2002-03$ & 0.62 & -0.14 \\
\hline $2003-04$ & 0.64 & 0.02 \\
\hline $2004-05$ & 0.66 & 0.02 \\
\hline $2005-06$ & 0.57 & -0.09 \\
\hline $2006-07$ & 0.76 & 0.19 \\
\hline $2007-08$ & 0.79 & 0.03 \\
\hline $2008-09$ & 0.95 & 0.16 \\
\hline $2009-10$ & 1.35 & 0.4 \\
\hline $2010-11$ & 1.08 & -0.27 \\
\hline $2011-12$ & 1.03 & -0.05 \\
\hline $2012-13$ & 0.98 & -0.05 \\
\hline $2013-14$ & 0.96 & -0.02 \\
\hline Source: Calculated by the authors based on Reserve Bank of India database \\
\hline
\end{tabular}


Therefore, from such meager government spending on health care, it is expected that the quantity and quality of the government health care services would be below standard as many empirical findings have shown (NEC, 2006). This phenomenon has got the potential to boost the OOP expenditure of the people, forcing them to treat themselves from their pockets when they face health shocks. As a result of which, many will make catastrophic payments, and so, many might fall back into the pool of poverty, and many, who are poor will be pushed deeper into the poverty trap. The OOP spending on health care in the state of Assam has been discussed in the following section.

Figure No.1: Diagrammatic representation of government spending on health care, Assam (\%of GSDP)

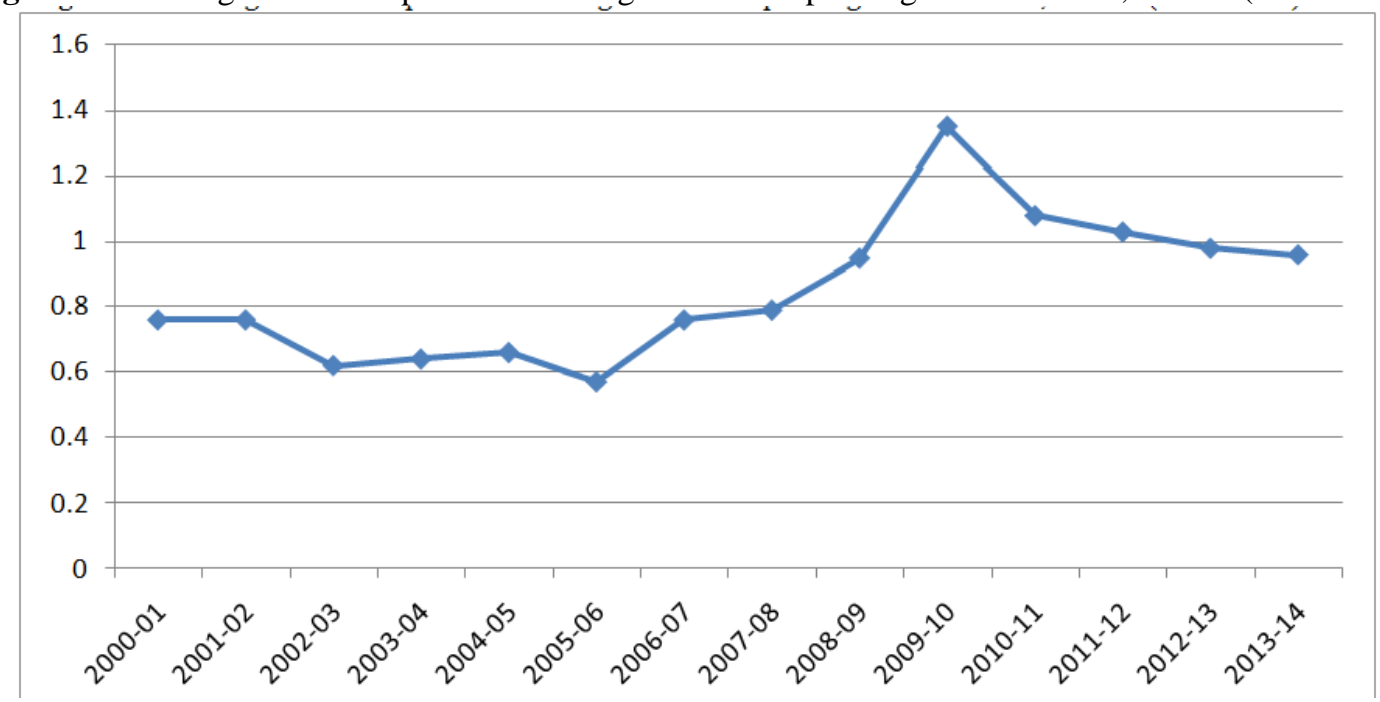

Source: Same as table 1

\section{IV.1. Out-of-Pocket Spending on Health Care in the State of Assam}

Table no. 3 shows the average total medical expenditure for treatment per hospitalization case during stay at hospital as inpatient over the last 365 days. It is shown separately for rural and urban areas. The total average OOP expenditure (rural + urban) is found to be Rs 14810. This is higher than the NER average of Rs 8770.88. In fact, both rural and urban expenditure is higher than the NER average, as has been shown in table 3. However, if we compare between rural and urban OOP expenses within the state, urban counterparts seem to be spending higher than the rural areas. This could be because the private clinics and hospitals are urban based, and the urban people can go to these private health care centres. On the other hand, people from the rural areas basically depend on the subsidized government health centres (namely sub-centre, Primary health centre and the Community Health Centre) irrespective of the quality of the services. Looking from gender perspective, the health care OOP spending of the female is higher than their male counterparts both in urban and urban plus rural, except in the rural areas. The reason could be that the female in the urban areas are more educated and better informed relative to the rural women. Furthermore, private but higher quality health services are more easily accessible in the urban areas compared to the rural areas. This could be because the rural areas are served by the subsidized public health care services as mentioned above.

Table No. 3: Average total medical expenditure (INR) for treatment per hospitalization case during stay at hospital (as inpatient) over last 365 days by residence and gender

\begin{tabular}{|l|c|c|c|c|c|c|c|c|c|}
\hline states & \multicolumn{9}{|c|}{ Average total medical expenditure for treatment (INR) per case } \\
\hline & \multicolumn{3}{|c|}{ Rural } & \multicolumn{3}{c|}{ Urban } & \multicolumn{3}{c|}{ Rural+Urban } \\
\hline & male & female & person & male & female & person & male & female & person \\
\hline Assam & 7313 & 6563 & 6966 & 31945 & 60152 & 47064 & 11589 & 18340 & 14810 \\
\hline $\begin{array}{l}\text { NER } \\
\text { Average* }\end{array}$ & 7082.00 & 5242.75 & 6110.13 & 15247.50 & 18275.88 & 16977.13 & 8934.63 & 8693.38 & 8770.88 \\
\hline All India & 17528 & 12295 & 14935 & 28165 & 20754 & 24436 & 21223 & 15292 & 18268 \\
\hline
\end{tabular}

Source: NSSO $71^{\text {st }}$ round; NOTE: NER=North Eastern Region of India, which consists of 8 states;

NOTE:*computed by the authors based on NSSO $71^{\text {st }}$ round data

OOP health care expenditure can be bifurcated into medical and non-medical expenditures. Medical expenditures are those expenses which are made on purchasing medicines, doctor's fee, diagnostic test and the like. The non-medical health care expenditures are those expenses which are made on transportation, food and 
lodging and even bribe payments to the health workers. Figure 2 depicts the medical and non-medical expenditures. It is being observed from the said figure, that the average medical expenditure and non-medical expenditure are higher than the All India average and NER average. For instance, the average medical expenditure for Assam is Rs 47064/-, and for the NER and All India they are Rs 16977.13/- and Rs 24436/respectively. For the non-medical health care expenditure the average is Rs 5304/-, Rs 3530.5 and Rs 2019 in Assam, NER and All India respectively. Therefore, the average OOP expenditure of Assam is seen to be high as compared to NER average and All India average.

The inpatient expenditure (IPD) on childbirth is also high in the state (table 4). For instance, the aforementioned table shows that the average expenditure on childbirth is Rs 4158/- in the rural areas, and Rs 11219/- in the urban areas. The NER average is Rs 3848.75/- in rural, and Rs 6384.25/- in urban areas. Thus, the OOP expenditure on childbirth in Assam is higher than the NER average, though lower than the All India average. Further, the OOP expenditure of the urban Assam on childbirth, both in the private hospitals and public hospitals are higher than the NER average and the All India average (table 4). But in the rural Assam the average spending is higher than NER and All India averages, in case of public hospitals but lower in case of expenditure in the private hospitals.

Figure No. 2: Average Medical Expenditure and Non-Medical Expenditure (INR) on account of hospitalization per hospitalization case

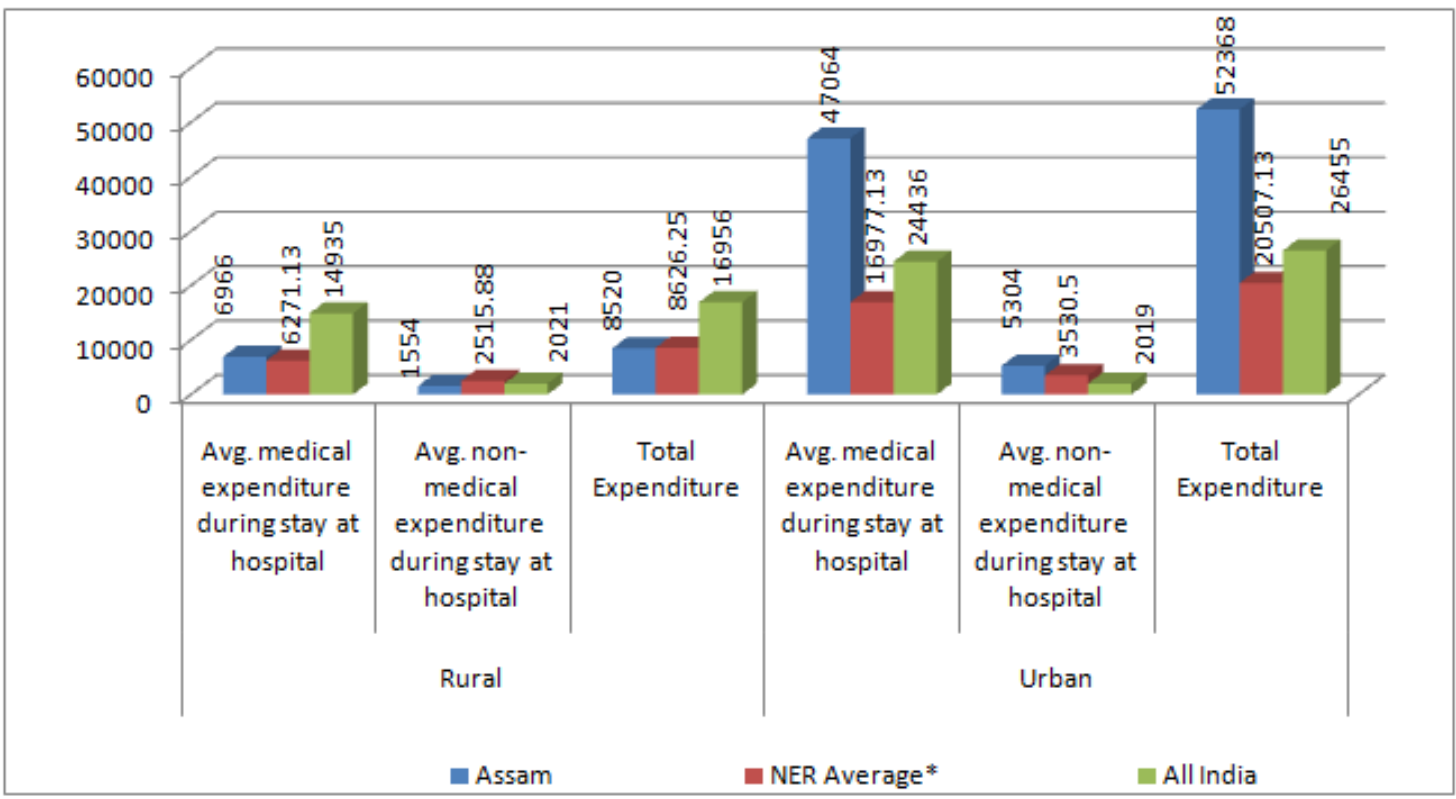

Source: NSSO 71 $1^{\text {st }}$ round; NOTE: NER=North Eastern Region of India, which consists of 8 states; NOTE:*computed by the authors based on NSSO $71^{\text {st }}$ round data

Table 5 shows the OOP expenditure by type of sickness and source of treatment. The outpatient (OPD) OOP expenditure is seen to be higher than the IPD OOP. The reason could be that, perhaps government insurance facilities like Rashtriya Swasthya Bima Yojana are helping people to get subsidized or free inpatient care or it could be that people are not seeking inpatient treatment due to lack of money and depend on over-thecounter treatment. On the other hand, the OPD OOP is high because people are not insured against outpatient treatment.

Table No. 4: Average total medical expenditure for treatment per childbirth during stay at hospital (as inpatient) over the last 365 days by type of hospital (Rural)

\begin{tabular}{|l|c|c|c|c|c|c|}
\hline \multirow{2}{*}{ State } & \multicolumn{5}{|c|}{ Average total medical expenditure for treatment (INR) per case } \\
\cline { 2 - 7 } & \multicolumn{5}{|c|}{ Urban } & \multicolumn{4}{c|}{ Rural } \\
\cline { 2 - 7 } & Public & Private & All & Public & Private & All \\
\hline$(1)$ & $(2)$ & $(3)$ & $(4)$ & $(5)$ & $(6)$ & $(7)$ \\
\hline Assam & 6949 & 30031 & 11219 & 3599 & 12502 & 4158 \\
\hline NER Average* & 3473.75 & 17605.25 & 6384.25 & 2702.13 & 13645.13 & 3848.75 \\
\hline All India & 2117 & 20328 & 11685 & 1587 & 14778 & 5544 \\
\hline
\end{tabular}

Source: NSSO $71^{\text {st }}$ round; NER=North Eastern Region of India, which consists of 8 states;

NOTE: $*$ computed by the authors based on NSSO $71^{\text {st }}$ round data 
Thus, the OOP spending of Assam on health care is found to be high. It is higher than the all India average, and NER average. This will have a negative repercussion on the health and wealth of the people, especially the poor ones, who do not have the financial capacity to cope with the high OOP spending when they get health shocks. Many poor will go untreated and many who needed to get inpatient treatment will not be able to make it and will end up with over-the-counter treatment from the local pharmacies. This will give health problems and prolonged disease burden to the individual and the family in the long run. Thus, the burden of disease/sickness and the basic health status of the people of the state will be pathetic. For instance, the maternal mortality of Assam from 2004-06 to 2011-13 far exceed the All India average (figure 3). Furthermore, the IMR of Assam has been higher than the IMR of all the north eastern states of India and the All India average and NER average (Srivastav and Basumatary, 2016) since 2005 to 2014. For instance, in 2005 the IMR of Assam was 68 per 1000 live births as against the NER average of 33.3 and All India average of 58. In 2014, the IMR of both Assam and all India average came down to 49 and the NER average came down to 28.2.

Table No. 5: Distribution of OOP by type of sickness/disease and source of treatment (in Rs. 000)

\begin{tabular}{|c|c|c|c|c|c|c|c|c|c|}
\hline State & OP Care & P Care & Delivery & ANC & PNC & $\begin{array}{l}\text { Abortion \& } \\
\text { Still Births }\end{array}$ & $\underset{\text { ion }}{\text { Immunizat }}$ & $\begin{array}{l}\text { At Death- } \\
\mathbb{P}\end{array}$ & $\begin{array}{l}\text { Total Health } \\
\text { Expenditure }\end{array}$ \\
\hline Assam & $\begin{array}{c}13,748,628 \\
(79.85)\end{array}$ & $\begin{array}{l}2,556,408 \\
(14.85)\end{array}$ & $\begin{array}{l}399,810 \\
(2.32)\end{array}$ & $\begin{array}{c}117,651 \\
(0.68)\end{array}$ & $\begin{array}{c}174,510 \\
(1.01)\end{array}$ & $\begin{array}{l}1,376 \\
(0.01)\end{array}$ & $\begin{array}{l}96,103 \\
(0.56)\end{array}$ & $\begin{array}{c}123,556 \\
(0.72)\end{array}$ & $\begin{array}{c}17,218,042 \\
(100)\end{array}$ \\
\hline $\begin{array}{l}\text { NER } \\
\text { Average* }\end{array}$ & $\begin{array}{c}2,303,374 \\
(74.68)\end{array}$ & $\begin{array}{l}593,151 \\
(19.23)\end{array}$ & $\begin{array}{l}80,801 \\
(2.62)\end{array}$ & $\begin{array}{l}23,186 \\
(0.75)\end{array}$ & $\begin{array}{l}29,406 \\
(0.95)\end{array}$ & $\begin{array}{l}1,144 \\
(0.04)\end{array}$ & $\begin{array}{l}17,007 \\
(0.55)\end{array}$ & $\begin{array}{l}36,053 \\
(1.17)\end{array}$ & $\begin{array}{c}3,084,122 \\
(100)\end{array}$ \\
\hline All India & $\begin{array}{c}614,774,538 \\
(68.17)\end{array}$ & $\begin{array}{c}218,333,022 \\
(24.21)\end{array}$ & $\begin{array}{c}31,925,528 \\
(3.54) \\
\end{array}$ & $\begin{array}{c}5,808,715 \\
(0.64)\end{array}$ & $\begin{array}{c}12,543,534 \\
(1.39)\end{array}$ & $\begin{array}{l}40,220 \\
(0.00)\end{array}$ & $\begin{array}{c}4,851,318 \\
(0.54)\end{array}$ & $\begin{array}{c}13,607,679 \\
(1.51)\end{array}$ & $\begin{array}{c}901,884,554 \\
(100)\end{array}$ \\
\hline \multicolumn{10}{|c|}{$\begin{array}{l}\text { Source: National Health Accounts, } 2004-05 \text { based on Health care and the condition of the aged, NSSO 60th round, (2006), Ministry of Statistic and } \\
\text { Programme Implementation, Government of India } \\
\text { NOTE:* computed by the authors based on NSSO } 71^{\text {st }} \text { round data; Figures in the parenthesis are in percentage and are computed by the authors }\end{array}$} \\
\hline
\end{tabular}

Figure No.3: Maternal Mortality Ratio for Assam

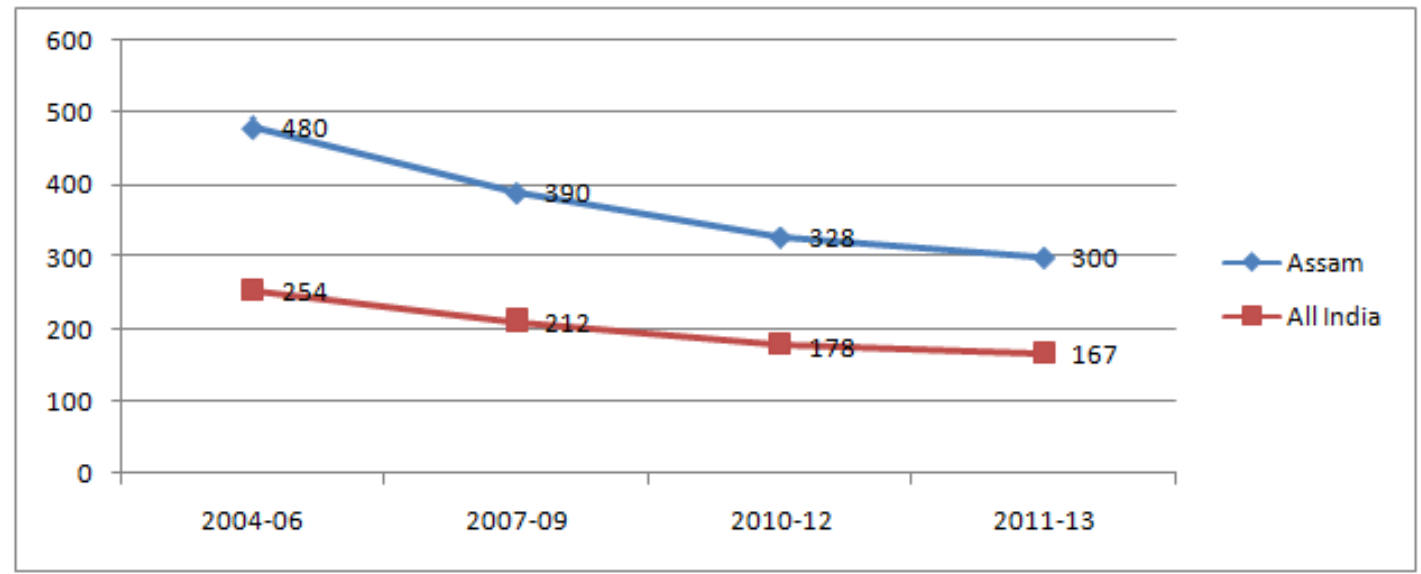

Source: Indiastats

Therefore, it is pertinent to look into the public spending on health care, so that less burden fall on the people in keeping themselves healthy and productive. The increase in public spending will help decrease the OOP on health care. This will go a long way in mitigating the menace of poverty, because it will have double positive effects in that the increase in public spending on health care will decrease the burden of OOP on the people. When people have to pay lesser from their pockets, their access to the health care when they get health shocks will increase, which will help them to stay healthy and more productive.

\section{CONCLUSION}

Out of pocket is regressive in nature, because lower-income groups pay disproportionately more of their income compared with higher-income groups. Thus, there is every chance that, the increase in the OOP spending on health care will make people poor who are at the threshold and pushed poor into poverty trap. It is true that spending on health care is an investment for an individual and for a state. However, when the capacity to spend itself is absent the meaning of investment becomes useless for the individuals. Thus, it is the 
responsibility of the state to augment the public spending on health care. However, the government spending on health care in Assam is found to be lower than 2\% of GSDP. The OOP of Assam is found to be high, rather higher than the NER average and the All India average. Thus, it is necessary to decrease the OOP spending by allocating more revenues to the health care sector. This will help people get better quality health care, and also protect them from securing their wealth and subsistence income. Hence, subsequently protect them from falling into the pool of poverty. Thus, it is suggested that the government spending on health care in Assam is increased to $2 \%$ (or more) of GSDP.

\section{REFERENCES}

[1]. Krishna, A. (2010). One illness away: Why people become poor and how they escape poverty. Oxford: Oxford University Press.

[2]. National Sample Survey Organization. Government of India. http://mospi.gov.in/national_data_bank/ndb-rpts-71.htm Accessed on 28 June 2016.

[3]. North Eastern Council, Government of India. Accessed on $27^{\text {th }}$ October, 2016 from http://www.mdoner.gov.in/content/poverty-estimates

[4]. Sample Registration System.Government of India, Ministry of Home Affairs. http://www.censusindia.gov.in/2011-common/Sample_Registration_System.html Accessed on 25 June 2016.

[5]. Srivastav, N and Basumatary, J.(2016). The major trends in public health care spending in India and its relationship with health care outcomes among north eastern states. Management in Health, 20(3), 13-27. http://journal.managementinhealth.com/index.php/rms/article/view/427

[6]. The World Health Statisitcs.(2012). World Health Organisation. Accessed on 27 Ocotber, 2016 from http://apps.who.int/iris/bitstream/10665/44844/1/9789241564441_eng.pdf

[7]. Wagstaff, A. and van Doorslaer, E. (2003).Catastrophe and impoverishment in paying for health care: with applications to Vietnam 1993-98. Health Economics, 12, 921-34.

[8]. Xu, K, Evans, D.B., Kawabata, K., Zeramdini, R., Klavus, J. \& Murray, C.J. (2003). Household catastrophic health expenditure: A multi-country analysis. THE LANCET, 362, 111- 